\title{
Examination Of The Influence Of Service Quality On Membership Renewal In Fitness Centers In San Francisco Bay Area
}

\author{
Pei Chih Wei, Hsin Sheng College of Medical Care and Management, Taiwan \\ Huang-Chia Hung, National Taitung University, Taiwan \\ Hiu-Chu Yang, National Taiwan College of Physical Education, Taiwan \\ Yu-Jui (Arthur) Hsu, Northwestern Polytechnic University, USA \\ Zhengwei Ma, Northwestern Polytechnic University, USA
}

\begin{abstract}
Corporations have to learn how to satisfy their customers'various demands as the era of interactivity with customers has emerged (Pepper \& Rogers, 1999). For fitness center, customers' demands are increasing and diversified. Therefore, service quality is an index of quality assessment from customers for service-producing industries. Furthermore, the concept of corporate expansion and customer relationship has become the foundation of service-providers for higher profitability through customers' renewal of membership. The main purpose of this study is to evaluate the impact of service quality on the renewal willingness of fitness center membership. Customers from four fitness centers in the San Francisco Bay Area, USA, were randomly selected for this survey. A total of 50 subjects participated in this survey. The data was analyzed by multiple regression and stepwise regression. The result indicated that the service quality has positive influence on the renewal willingness of membership.
\end{abstract}

Keywords: Fitness Center, Service Quality, Renewal Willingness, Behavior Intention

\section{CHAPTER ONE: INTRODUCTION}

\section{Background}

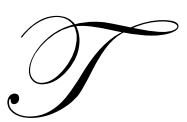

he economy is growing rapidly nowadays and living standard is increasing higher. The technology evolves everyday. Instead of repeatedly using traditional way of handing housework, most people take advantage of modern technology and use latest products to make their life easier, resulting in reduction of exercise. In addition, unhealthy and obsessive eating behavior also contributes to the growth of civilization diseases. For relaxation by engaging more recreational activities outdoor, people can only utilize their time after work or take a vacation occasionally. However, people actually would expect to enjoy more their life from leisure activities in addition to their work and daily routines. People relax themselves by taking a walk after work or taking a vacation. But the most important thing they want is the enjoyment of leisure experience. Relevant medical science articles have been published constantly regarding this issue. Although "how to live healthier and safer" is what people care the most, most people still focus on searching "professional consultation in sports for healthy living style". Recently, the pursuit of fashionable recreational sports becomes a trend. Basically, apart from leisure venues and sports facilities, consumers would further like to receive comfortable and perfect services.

\section{Research Motivation}

According to the report by International Health, Racquet and Sportsclub Association (IHRSA) in January, 2001, there were 6,211 health and fitness clubs in USA in 1982. The number of clubs increased to 9,222 in 1985. The total members of these clubs amounted to 13.8 millions in 1985. In January 2002, health and fitness clubs had been soaring up to 17,807 with total members of 33.8 millions. This report indicates that the total number of the fitness centers had jumped 30-fold in 20 years in between 1982 and 2002. The total number of members had been growing steadily since 1982. Due to the change of consumption patterns and the rise of consumer awareness, the competition in marketing becomes fiercer. Therefore, it is particularly important for fitness centers to retain their 
existing customers. While more interactive with customers, fitness centers should learn how to satisfy various needs of their customers. (Pepper \& Rogers, 1999).

During the last decade, the interest of both marketing practitioners and scholars alike regarding the notion of "customer value" has increased (Gale, 1994). Although delivering superior customer value is an important factor for fitness centers' success. (e.g., Bolton and Drew, 1991; Gronroos, 1994, 1997; Zeithaml et al., 1996; Parasuraman, 1997), researchers have also acknowledged the importance of customer value for improving the performance program of customer's relationship management (Day, 1994; Slater, 1997; Wang et al., 2004). For fitness centers, aiming at stabilizing customer segments can be more profitable than investing more capitals in marketing. Good customer relationship is significant intangible assets for fitness centers. If fitness centers ignore the business relations with customers, customer loyalty will gradually be eroded. As a result, the fitness centers will gradually lose this asset which will impact their revenues and profitability (Anton, 1996).

Therefore, this research is to study the impact of fitness center's service quality on customer's renewal willingness and in hope that the findings will be used to provide a better strategy for managing fitness centers.

\section{Research Purposes}

Based on the research motivation and background, this study is to further explore the relationship between fitness center's service quality and consumer's renewal willingness to establish a suitable theoretical model. Facing with fierce competitions, fitness centers should let consumers have their own choices of selecting their preferred fitness center in order to improve service quality and achieve a lower customer attrition rate. This is the primary focus of this study.

It is hoped that the results of this study will provide fitness centers industry with a better marketing strategy to be more in line with the direction of current marketing trend.

\section{CHAPTER TWO: LITERATURE REVIEW}

This chapter consists of four sections, including the origin of fitness center and, the definitions of terms used in these articles.

\section{The origin of Fitness Center}

The first fitness health club in the U.S. was originated from Young Men's Christian Association (YMCA) in the 1950s. After the 1970s, fitness centers have been constantly growing. Many products and industries pertaining to fitness center have emerged, such as squash rackets and tennis club. At the same time, the aerobic industries were popular around the world and the US fitness center industries developed stronger day by day. Finally, the USA fitness center approached to a new milestone (Patton, 1989). At the same time, aerobics had become popular all over the world. In the meanwhile, the fitness center industry had gradually developed and become more robust, and entered to a new milestone. In 1998, a report of IHRSA revealed that there were 6,211 clubs in 1982 in the US. By July 2004, the total number of clubs had reached 22,031 with more than 36.3 million members. (IHRSA, 2004)

The motivation and reason to join club are based on different economic dimensions. The personal reasons could be the cost and benefits received from club by individual (Buchanan,1965).

\section{Service Quality}

Service quality is determined by customer satisfaction through services being provided, and in turn, it affects customer's loyalty (Bitner, 1990).

The "service quality" in this study is indicated and evaluated by the answers provided from the questionnaires pertaining to fitness center's service quality. The higher score means that the service quality provided by fitness centers is also better.

\section{Renewal Willingness}

Renewal willingness in this article refers to a member's willingness for the renewal of membership or enrollment to new fitness program provided by one's fitness center and the intention to recommend to others based on one's positive experiences. (Hepworth \& Mateus, 1994) 


\section{Behavioral Intention}

Behavioral intention is to explain behavioral processes. The intention indicates that "the decision- making process of choosing a behavior" results in "the extent of expression of whether engaging a behavior". Cronin and Taylor (1992) investigated the conceptualization and measurement of service quality and the relationship between consumer satisfaction and purchase intentions. To measure the behavior intention of customers, Boulding (1993) used two questionnaires which were the desire of renewal willingness and the intention of recommendation to others. Behavior intention is a reaction of customer satisfaction by comparing their expectation of the products with their actual experience of using the products. In short, a satisfied customer will give the company a positive evaluation such as reputation and customer recognition.

\section{Proposed Model - Framework}

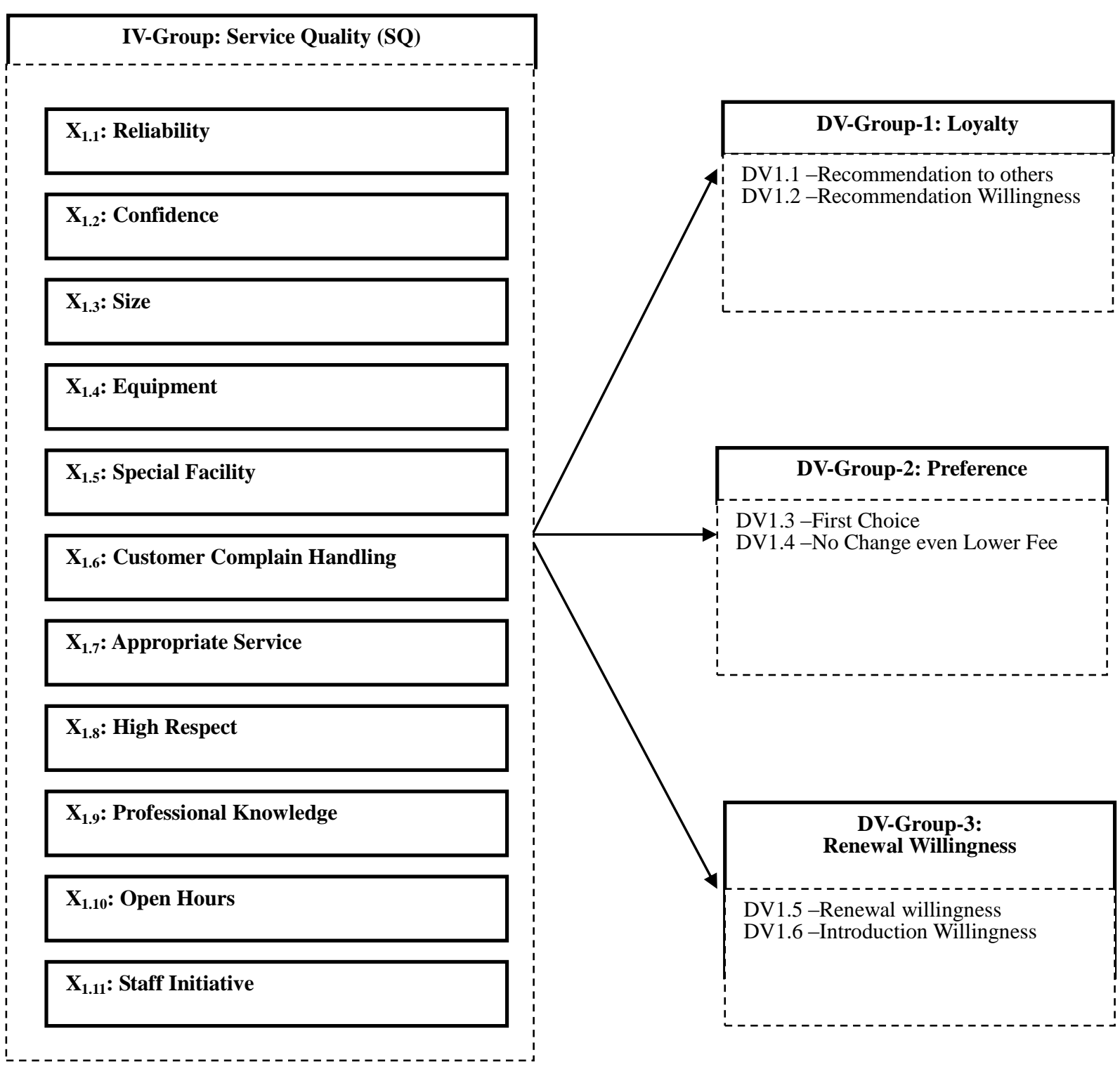

Figure 2.1 Proposed Models - Framework

DV: Dependent Variable IV: Independent Variable - Figure 1. 


\section{Summary}

According to the literature review and the definition of DV and IV, the researcher builds up the research framework. This research framework displays the correlation between the dependent variables and the independent variables, which also becomes the base of research methodology of next chapter.

Table 2 - 1 Dependent and Independent Variables and Survey Questions

\begin{tabular}{|c|c|c|c|}
\hline \multicolumn{2}{|c|}{ Dependent variables } & Author & Survey question \\
\hline \multirow{3}{*}{ Renewal willingness } & $\begin{array}{l}\text { Recommendation to } \\
\text { the others }\end{array}$ & Fornell (1992) & $\begin{array}{ll}\text { (1.1) I am willing to recommend advantages of } \\
\text { my fitness center to others. } \\
\text { (1.2) If asked, I am willing to recommend this } \\
\text { fitness center. }\end{array}$ \\
\hline & Loyalty & $\begin{array}{l}\text { Hepworth \& Mateus } \\
\text { (1994) }\end{array}$ & $\begin{array}{l}\text { This fitness center would be my first } \\
\text { choice. } \\
\text { I wouldn't change fitness center, even if } \\
\text { membership fees are lower in others }\end{array}$ \\
\hline & Renewal fee & $\begin{array}{l}\text { Hepworth \& Mateus } \\
\text { (1994) }\end{array}$ & $\begin{array}{l}\text { (1.5) I am willing to renew membership in this } \\
\text { fitness center. } \\
\text { (1.6) I am willing to introduce my fitness center } \\
\text { to my friends. }\end{array}$ \\
\hline \multicolumn{2}{|c|}{ Independent variables } & Author & Survey Question \\
\hline \multirow{5}{*}{ Service Quality } & Reliability & Bitner (1990) & $\begin{array}{l}\text { (1.1) My fitness center is reliable. } \\
\text { (1.2) I have confidence in my fitness center. }\end{array}$ \\
\hline & Facility & Juran (1989) & $\begin{array}{l}\text { (1.3) I am satisfied with the size of my fitness center. } \\
\text { (1.4) I am satisfied with the equipments in my } \\
\text { fitness center. } \\
\text { (1.5) I'm satisfied with the special facilities } \\
\text { provided by my fitness center. (For } \\
\text { example: swimming pool, sauna room, } \\
\text { etc.) }\end{array}$ \\
\hline & Responsiveness & Oliver (1993) & $\begin{array}{l}\text { Will your fitness center handle customer } \\
\text { complain promptly? } \\
\text { My fitness center would provide me with } \\
\text { appropriate service when I need them. }\end{array}$ \\
\hline & Guaranteed & Bitner (1990) & $\begin{array}{l}\text { Fitness center highly respect members' } \\
\text { rights. } \\
\text { Instructors have enough professional } \\
\text { knowledge to solve members' problems. }\end{array}$ \\
\hline & Hospitality & Levitt (1972) & $\begin{array}{l}\text { I am satisfied with fitness center open } \\
\text { hours. } \\
\text { Fitness center staff greets members } \\
\text { initiatively }\end{array}$ \\
\hline
\end{tabular}

\section{CHAPTER THREE: RESEARCH METHODOLOGY}

\section{Research Questions}

(1) Is there a significant relationship between fitness center's customer service quality and renewal willingness?

\section{Population and Sample}

(1) Population: The populations targeted are members of fitness center in San Francisco Bay Area, USA

(2) Sample: A random sample of 50 people was taken from the following four fitness centers: Touchstone San Climbing, 24 Hour Fitness, U.S. Fitness Pros, and Right Stuff Health Clubs 


\section{Data Collection}

The survey was conducted from September 20, 2009 to December 12, 2009. The questionnaires were collected from the 50 people and the data were entered into an Excel spreadsheet for analysis.

\section{Pilot Test for Data Reliability}

Cronbach's alpha is a statistic commonly used as a measure of the internal consistency or reliability of a psychometric test score for a sample of examinees. Alpha can take values between negative infinity and 1 . As a rule of thumb, an alpha value of 0.70 or higher is considered reliability. In this initial stage, pilot test was performed by calculating Cronbach's alpha using all survey questions aforementioned (i.e. all dependent and independent variables in Table 2). The result is shown as follows.

Table 3 - 1 Reliability Statistics

\begin{tabular}{|c|c|}
\hline Cronbach's Alpha & N of Items \\
\hline .894 & 17 \\
\hline
\end{tabular}

\section{Pearson Correlation}

Pearson correlation is a measure of the correlation (linear dependence) between two variables $X$ and $Y$, giving a value between +1 and -1 inclusive. It is widely used in the sciences as a measure of the strength of linear dependence between two variables. The researcher removed five dependent variables (Advantage Promotion, Recommendation Willingness, First Choice, Low Fee No Change, Introduction Willingness) and kept one dependence variable (Renewal Willingness).

\section{Hypothesis and Variables}

Based on the research question, the researcher developed the dependent variable and independent variable in the following hypothesis.

(1) Hypothesis : Renewal willingness is highly correlated with the service quality

Dependence Variable (DV): Renewal Willingness

Independence Variable (IV): Service Quality

Statistical Methodology: Multiple Regression (Mertler \& VANNATTA, 2005)

Table 3 - 2 Service Quality (11 dimensions):

\begin{tabular}{|l|l|l|l|}
\hline$X_{1.1}$ & Reliability & $X_{1.2}$ & Confidence \\
\hline$X_{1.3}$ & Size & $X_{1.4}$ & Equipment \\
\hline$X_{1.5}$ & Special Facility & $X_{1.6}$ & Customer Complain Handling \\
\hline$X_{1.7}$ & Appropriate Service & $X_{1.8}$ & High Respect \\
\hline$X_{1.9}$ & Professional Knowledge & $\mathrm{X}_{1.10}$ & Open Hours \\
\hline$X_{1.11}$ & Staff' Initiative & \multicolumn{2}{|l}{} \\
\hline
\end{tabular}

\section{CHAPTER FOUR: DATA ANALYSIS}

In this chapter, the researcher pre-analyzed and pre-screened the raw data, and interpreted the execution process of quantitative method of multiple regression using SPSS.

\section{Multiple Regression -Testing of Hypothesis}

Group: Renewal Willingness (DV) - Service Quality (IV)

Hypothesis: Renewal Willingness is highly correlated with the Service Quality (Reliability, Confidence, Equipment, Special Facility, Customer Complain Handling, Appropriate Service, High Respect,: Professional Knowledge, Open Hours, Staff Initiative) 
Table 4-1 ANOVA

\begin{tabular}{|l|c|c|c|c|c|}
\hline \multicolumn{1}{|c|}{ Source } & df & Sum of Squares & Mean Square & F-test & P-value \\
\hline Regression & 11 & 66.816 & 6.074 & 4.957 & $<.0001$ \\
\hline Residual & 38 & 46.564 & 1.225 & & \\
\hline Total & 49 & 113.380 & & & \\
\hline $\mathbf{R}=\mathbf{0 . 7 6 8}$ & & & \\
$\mathbf{R}^{2}=\mathbf{0 . 5 8 9}$ & & & & \\
Adjusted $\mathbf{R}^{2}=\mathbf{0 . 4 7 0}$ &
\end{tabular}

Table 4 - 2 Regression Coefficients

\begin{tabular}{|c|c|c|c|c|c|}
\hline \multirow[b]{2}{*}{ Independent Variable } & \multicolumn{2}{|c|}{ Unstandardized Coefficients } & \multirow{2}{*}{$\begin{array}{c}\begin{array}{c}\text { Standardized } \\
\text { Coefficients }\end{array} \\
\text { Beta } \\
\end{array}$} & \multirow[b]{2}{*}{ t-test } & \multirow[b]{2}{*}{ P-value } \\
\hline & Beta & Std. Error & & & \\
\hline Intercept & -.772 & 1.316 & & -.587 & .561 \\
\hline $\mathrm{X}_{1.1}:$ Reliability & -.072 & .291 & -.050 & -.249 & .805 \\
\hline $\mathrm{X}_{1.2}:$ Confidence & .249 & .332 & .176 & .751 & .457 \\
\hline $\mathrm{X}_{1.3}:$ Size & .256 & .155 & .268 & 1.653 & .107 \\
\hline $\mathrm{X}_{1.4}$ : Equipment & .226 & .266 & .206 & .850 & .401 \\
\hline $\mathrm{X}_{1.5}:$ Special Facility & -.084 & .172 & -.093 & -.491 & .626 \\
\hline $\mathrm{X}_{1.6}:$ Customer Complain Handling & -.042 & .214 & -.030 & -.197 & .845 \\
\hline $\mathrm{X}_{1.7}:$ Appropriate Service & .097 & .281 & .075 & .345 & .732 \\
\hline $\mathrm{X}_{1.8}$ : High Respect & .015 & .269 & .011 & .056 & .955 \\
\hline $\mathbf{X}_{1.9:}$ Professional Knowledge & -.379 & .177 & -.324 & -2.140 & .039 \\
\hline $\mathrm{X}_{1.10}:$ Open Hours & .089 & .137 & .087 & .653 & .518 \\
\hline $\mathrm{X}_{1.11}$ : Staff Initiative & .694 & .143 & .639 & 4.862 & $<.0001$ \\
\hline
\end{tabular}

The general model for the hypothesis of present study:

$\mathbf{Y}($ Renewal Willingness $)=-0.772-0.072 \mathrm{X}_{1.1}+0.249 \mathrm{X}_{1.2}+0.256 \mathrm{X}_{1.3}+0.226 \mathrm{X}_{1.4}-0.084 \mathrm{X}_{1.5}-0.042 \mathrm{X}_{1.6}+$ $0.097 \mathrm{X}_{1.7}+0.015 \mathrm{X}_{1.8}-0.379 \mathrm{X}_{1.9}+0.089 \mathrm{X}_{1.10}+0.694 \mathrm{X}_{1.11}$

\section{Discussion of Hypothesis Testing Results}

The testing of the hypothesis and the results were reported in detail in this section

\section{Multiple Regression and Stepwise Analyses}

\section{Multiple Regression}

Multiple regression analysis was performed and the results were summarized and presented in Table 4-1 and Table 4-2. The ANOVA summarized in Table 4-1 indicates that the overall model of the 11 IVs significantly predicted Renewal Willingness with $\mathrm{R}=0.768, \mathrm{R}^{2}=0.589$, adjusted $\mathrm{R}^{2}=0.470, \mathrm{~F}(11,38)=4.957$, and $\mathrm{p}$-value $<0.001$. The results reveal that Renewal Willingness is highly correlated to Service Quality ( $\mathrm{p}$-value $<.05$ ). In the meantime, the results support the hypothesis that 11 dimensions (i.e. IVs) were significantly correlated with Renewal Willingness of customers. In addition, the statistical result also shows that Professional Knowledge and Staff Initiative were significant predictors of customer's Renewal Willingness. Although Size ( $p$-value $=0.107)$ was a not statistical significant at 0.05 level, it was trending toward significance. The variable "Size" should not be neglected.

\section{Stepwise Analyses for the Hypothesis}

In the statistical results presented above, the stepwise regression analysis using SPSS statistical software was conducted to develop a compact model for the hypothesis. First, this analysis could reduce or eliminate the collinearity among variables. Second, this analysis was to identify the most important ones among those eleven Service Quality dimensions. The results of stepwise regression analysis for the hypothesis, using alpha=0.05 for variable entry and alpha=0.1 for variable removal, were summarized in Tables 4-3 to 4-5. Based on the model summary in Table 4-3, it is suggested that Model 3 with the highest adjusted $\mathrm{R}^{2}$ of 0.495 could represent the 
compact model for the hypothesis, with the dependent variable being Renewal Willingness and the independent variables being Professional Knowledge, Staff Initiative and Size.

A stepwise regression analysis helps to improve the issues of co-linearity among the variables. The collinearity statistics need scrutiny when the independents are highly intercorrelated. The tolerance for a variable is $\left(1-\mathrm{R}^{2}\right)$ for the regression of that variable on all the other independent variables, ignoring the dependent variable. When tolerance is close to 0 there is high multi-collinearity of that variable with other independent variables. The statistical analysis results for the hypothesis imply that multi-collinearity was not a distinct problem since the tolerance value for the 11 variables ranges from 0.58 to 1 (Mertler \& Vannatta, 2001). Thus, the statistical analysis results of the hypothesis using a stepwise regression indicate that three variables, Professional Knowledge, Staff Initiative and Size, were statistical significant predictors of Renewal Willingness.

The regression equation arrived in a sequence of multiple linear regression equations, in a stepwise manner. At each step of the sequence, one variable is added to the regression equation. The variable added is the one that makes the greatest reduction in the error sum of squares of the sample data. Equivalently, it is the variable that when added, provides the greatest increase in the $\mathrm{F}$ value. Consequently, the result showed that one variable, Size, which had not been statistically significant when analyzed by multiple regression, was then statistically significant via the stepwise analysis. In other words, it would be reasonable to include variable Size as one of the important dimensions of Service Quality in predicting Renewal Willingness. In addition to the model shown in Table 4-3, the estimates of the slopes (i.e. betas) of variables by stepwise regression were presented in Table 4-4.

\section{The compact model selected by stepwise regression:}

$\mathrm{Y}($ Renewal Willingness $)=0.294+0.387 \mathrm{X}_{1.3}-0.288 \mathrm{X}_{1.9}+0.758 \mathrm{X}_{1.11}$

Table 4 - 3 Stepwise Regression - Model Summary

\begin{tabular}{|c|c|c|c|}
\hline Model & R & R Square & Adjusted R Square \\
\hline 1 & $.628(\mathrm{a})$ & .394 & $\mathbf{3 8 1}$ \\
\hline 2 & $.694(\mathrm{~b})$ & .482 & $\mathbf{4 6 0}$ \\
\hline 3 & $.725(\mathrm{c})$ & .526 & $\mathbf{4 9 5}$ \\
\hline
\end{tabular}

a Predictors: (Constant), $\mathrm{X}_{1.11}$ (Staff Initiative)

b Predictors: (Constant), $X_{1.11}$ (Staff Initiative),$X_{1.3}$ (Size)

c Predictors: (Constant), $\mathrm{X}_{1.11}$ (Staff Initiative), $\mathrm{X}_{1.3}$ (Size), $\mathrm{X}_{1.9}$ (Professional Knowledge)

Table 4 - 4 Stepwise Regression Coefficients

\begin{tabular}{|c|c|c|c|c|c|}
\hline \multirow[b]{2}{*}{ Source } & \multicolumn{2}{|c|}{$\begin{array}{l}\text { Unstandardized } \\
\text { Coefficients }\end{array}$} & \multirow{2}{*}{$\begin{array}{c}\begin{array}{c}\text { Standardized } \\
\text { Coefficients }\end{array} \\
\text { Beta }\end{array}$} & \multirow[b]{2}{*}{ t-test } & \multirow[b]{2}{*}{ p-value } \\
\hline & Beta & Std. Error & & & \\
\hline (Constant) & .294 & .820 & & .359 & .722 \\
\hline $\mathrm{X}_{1.11}:$ Staff Initiative & .758 & .116 & .697 & 6.531 & $<.001$ \\
\hline $\mathrm{X}_{1.3}:$ Size & .387 & .109 & .405 & 3.542 & .001 \\
\hline $\mathrm{X}_{1.9}$ : Professional Knowledge & -.288 & .139 & -.247 & -2.071 & .044 \\
\hline
\end{tabular}

Dependent Variable: Renewal Willingness 
Table 4-5 Stepwise Regression - Excluded Variables

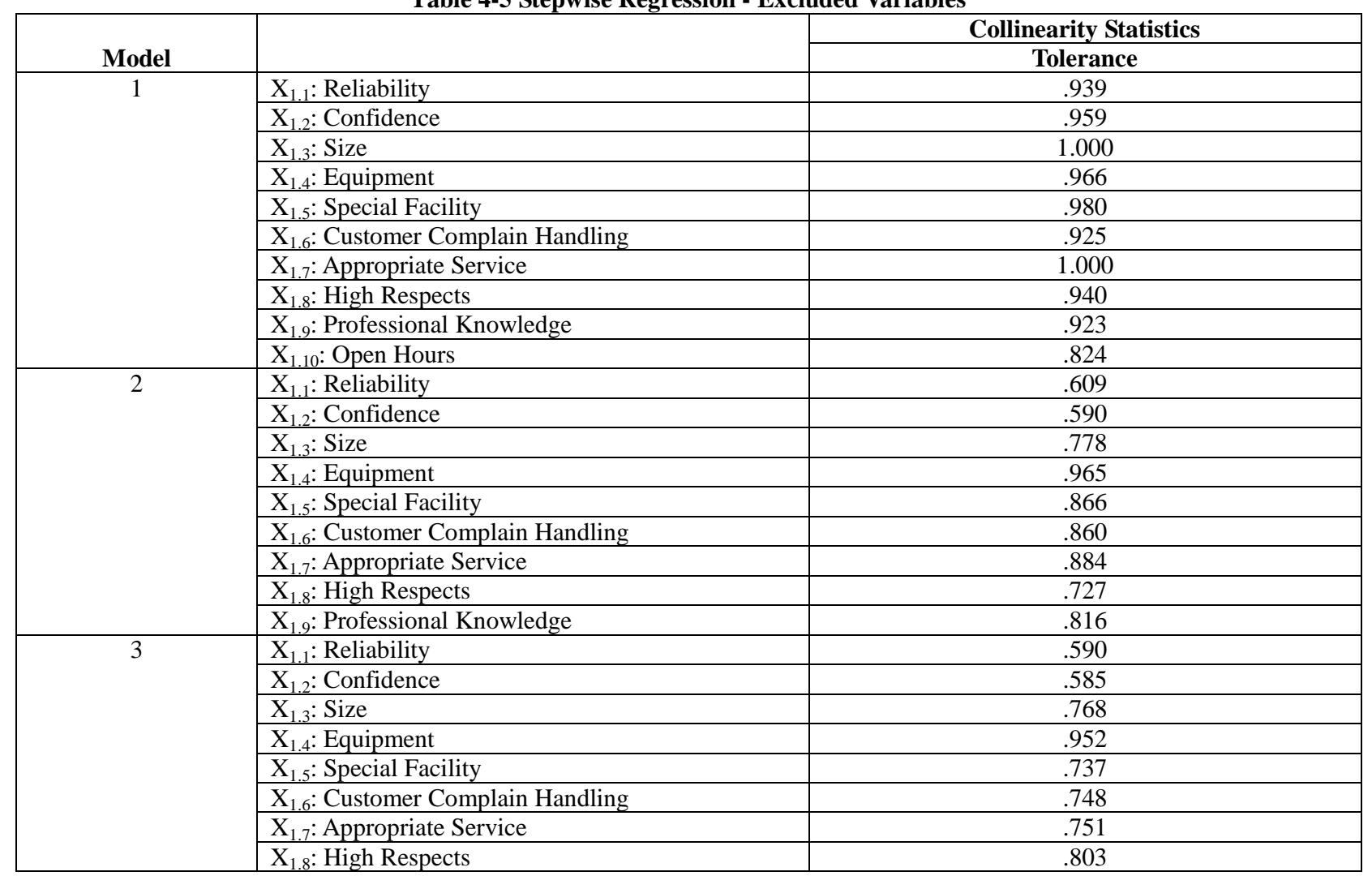

a. Predictors: (Constant), $\mathrm{X}_{1.11}$ (Staff Initiative)

b. Predictors: (Constant), $X_{1.11}$ (Staff Initiative), $X_{1.3}$ (Size)

c. Predictors: (Constant), $\mathrm{X}_{1.11}$ (Staff Initiative), $\mathrm{X}_{1.3}(\mathrm{Size}), \mathrm{X}_{1.9}$ (Professional Knowledge)

To increase customer renewal willingness, fitness centers should emphasize on service quality. There are three major dimensions in enhancing service quality of fitness center, which are Staff Initiative, Size and Professional Knowledge. Therefore, fitness centers should focus on these three primary dimensions when developing effective business strategies. 


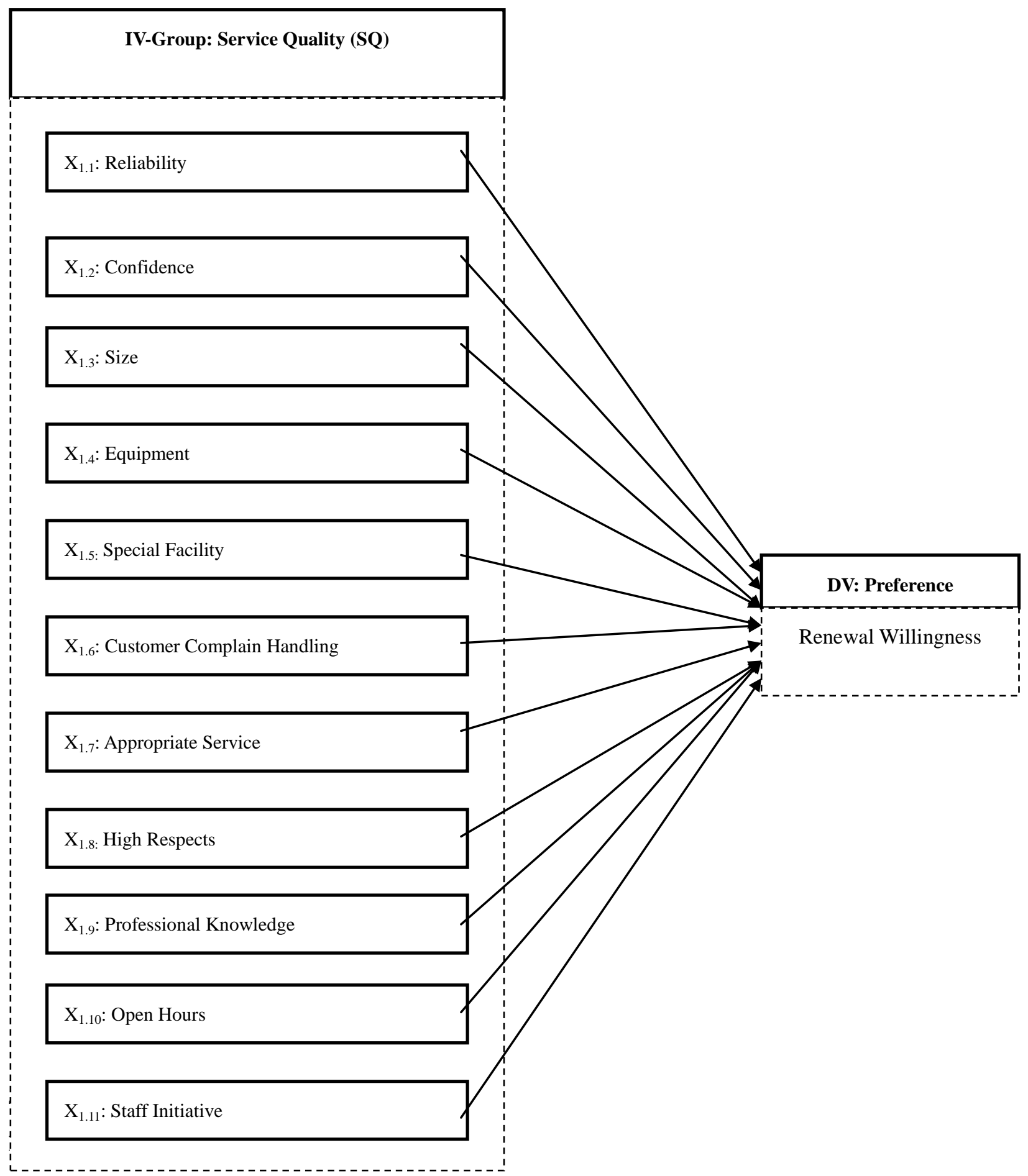

Figure 4.1 Overall Proposed Model 


\section{CHAPTER FIVE: CONCLUSION AND CONTRIBUTION}

There are three sections in this chapter. The first section is the analysis and finding of the overall model. The second section is research hypothesis and result identified. The last section presents the research conclusion and suggestion according to the analysis result.

\section{Analysis and Finding of the Overall Model}

This research constructed the theoretical model by literature review and randomly selected the members from various fitness centers as the research target. Based on multiple regression analysis, the results indicated that the overall theoretical model was acceptable and supported by the data collected. Therefore, the model which consists of "Service Quality" and "Renewal Willingness" could be applied to fitness industries.

\section{Research Hypothesis and Result Identified}

Upon examination of the hypothesis, $\mathrm{R}^{2}$ of 0.589 from multiple regression analysis indicated that renewal willingness was highly correlated with service quality. Furthermore, three IVs, "Staff Initiative", "Size" and "Professional Knowledge" representing service quality weree selected as significant predictors of renewal willingness based on stepwise regression analysis. Among these three, "Staff Initiative" was the most significant one $(\mathrm{p}<0.001)$, which was most influential on renewal willingness. In particular, if the staffs of fitness center were more attentive to their customers with passion, treating them like a family member, the customers would be much satisfied with the services of the fitness center provided. It seems to the researcher that it is essential and imperative for running the fitness center with strong staff initiative.

In addition, "Size" (i.e. size and space of fitness center) which was part of "Service Quality" was also a significant predictor $(\mathrm{p}=0.001)$ for "Renewal Willingness". It is worth noting that the future expansion or renovation of a fitness center may enhance "Renewal Willingness" of their customers.

The third significant predictor $(\mathrm{p}=0.044)$, Professional Knowledge, based on stepwise regression which had a negative linear relationship with Renewal Willingness (slope $=-0.288$ ).

It is interesting to note that Professional Knowledge was a more significant predictor from multiple regression analysis $(\mathrm{p}=0.039)$ then that from stepwise regression analysis. However, Size was significant in stepwise regression analysis $(\mathrm{p}=0.001)$ rather than in multiple regression $(\mathrm{p}=0.107)$. This may indicate that the collinearity among the IVs may need further investigation in future researches.

\section{Service Quality Improvement}

When fitness center has a nice relationship with customers, the interaction with their customers will also be positive. As such, the service quality of fitness center could also be improved. In addition, when the customers have any questions, fitness center can provide a specialist or various alternatives (including telephone hot-line or website) to resolve their problems promptly. This could increase customer's overall confidence level, satisfaction and loyalty dramatically.

Finally, when the price of membership renewal fluctuates due to overall economy, customers will be likely to stick with their fitness center due to the service quality experienced. This finding is consistent with the research result of Crosby et al. (1990).

\section{Conclusions and Recommendations}

Under the research framework, the analysis results of the empirical data collected had validated the applicability of the model. At the same time, the results contributed greatly to the practical application in fitness center industry. Pursuing growth and profitability is an important course to all businesses. It is not only to increase market shares, but also to pursue profits generated from customers' long-term loyalty. 
In general, the renewal willingness of consumers usually depends on the reputation of fitness center. Fitness center can focus on customers of various groups to expend their programs for more versatile services, such as customized service for individual's needs. It would boost business reputation and customer's loyalty, and even help with customer retention rate. profitable.

If these goals can be achieved, the fitness center will not only be more competitive, but also more

\section{BIBLIOGRAPHY}

1. $\quad$ Anton, J. (1996). Customer relationship management. Prentice Hall

2. Boulding,W.,Kalra,A.,Staelin,R., \& Zeithaml,V.A. (1993). A dynamic process model of service quality: From expectation to behavioral intentions. Journal of Marketing Research, 15(1), 7-27.

3. $\quad$ Buchanan, J.M. (1965), "An economic theory of clubs", Economicia, 32(125), 1-14.

4. Bitner, M.J. (1990), "Evaluating service encounters: the effects of physical surroundings and employee responses", Journal of Marketing, 54, 69-82.

5. Bolton, R. N. y Drew, J. H. (1991a). A multistage model of customer's assessments of service quality and value. Journal of Consumer Research, 17(4), 375-384.

6. Cronin, J.J., \& Steven, A.T.(1992). Measuring Service quality: A Reexamination and Extension. Journal of Marketing, 56(July), 55-68.

7. Craig A. Mertler, Rachel A. Vannatta. (2005). Advanced and multivariate statistical methods: practical application and interpretation. Glendale, CA : Pyrczak, c2005.

8. Day, G. (1994). "The capabilities of market-driven organizations," Journal of Marketing, 58(4), 37-52.

9. $\quad$ Gale, B.T. (1994). Managing Customer Value, Free Press, New York, NY.

10. Hepworth, M. and P. Mateus (1994). Connecting customer loyalty to the bottom line. Canadian Business Review, 21(4), 40-43.

11. IHRSA(2004).Trend Report 2004, July 2004: IHRSA

12. Juran, J. M. (1989). A universal approach to managing for quality. Quality Progress, 6(5), 15.

13. Levitt, T. 1972. Production-line approach to service. Harvard Business Review, 50(2): 41-52.

14. Mertler, C. A., \& Vannatta, R. A. (2001). Advanced and Multivariate Statistical Methods: Practical Application and Interpretation. Los Angeles: Pyrczak Publishing.

15. Oliver, R. L.(1993). Contitive, affective, and attribute bases of the satisfaction .Journal of Customer Research, 20(40), 418-430.

16. Patton, R,W., Granthan, W.C., Gerson R., \& Gettman (1989). Developing and Managing Health/Fitness Facilities. Champaign, llinois: Human Kinetics Books.

17. Peppers, D., Roger, M., \& Dorf, R. (1999). Is your Company Ready for one-to-one Marketing. Harvard Business Review, (Jan-Feb), 151-160.

18. Parasuraman, A.,Zeithaml V. \& Berry L.(1985). "A Conceptual Model of Service Quality and Its Implications for Future Research". Journal of Marketing, 49, 41-50.

19. Parasuraman, A. (1997). "Reflections on gaining competitive advantage through customer value," Journal of the Academy of Marketing Science, 25(2), 154-161

20. Slater, S.F. (1997). "Developing a customer value-based theory of the firm," Journal of the Academy of Marketing Science, 25(2), 162-167.

21. Storbacka, K., T. Standvik, and C. Gronroos (1994). "Managing customer relationships for profit: The dynamics of relationship quality," International Journal of Service Industry Management, 5(5), 21-38.

22. Wang, Y., Lo, H.P., Chi, R., and Yang, Y. (2004). "An integrated framework for customer value and customer-relationship-management performance: A customer based perspective from China," Managing Service Quality, 14(2-3), 169-182.

23. Zeithaml, V.A., Berry, L., \& Parasuraman, A. (1996). "The behavioral consequences of service quality," Journal of Marketing, 60(2), 31-46. 
NOTES 